\title{
Influence of Postharvest Treatment on Physical Characteristics and Mineral Content of Mango (Mangifera Indica L) Fruit in Arba Minch, Southern Ethiopia
}

\author{
Gizachew Girma*, Gezahegn Garo, Seifu Fetena \\ Department of Horticulture, College of Agricultural Sciences, Arba Minch University, Arba Minch, Ethiopia
}

Email address:

gizachewg323@gmail.com (G. Girma)

${ }^{*}$ Corresponding author

\section{To cite this article:}

Gizachew Girma, Gezahegn Garo, Seifu Fetena. Influence of Postharvest Treatment on Physical Characteristics and Mineral Content of Mango (Mangifera Indica L) Fruit in Arba Minch, Southern Ethiopia. International Journal of Nutrition and Food Sciences.

Vol. 5, No. 6, 2016, pp. 395-400. doi: 10.11648/j.ijnfs.20160506.14

Received: August 22, 2016; Accepted: September 1, 2016; Published: November 3, 2016

\begin{abstract}
The trial was carried out to explore the influence of packaging material and storage period on physical characteristics and mineral content of mango fruit at cool chamber and open air.The experimental treatments were comprised storage conditions (open air and pusa zero energy cool chamber), packaging materials (plastic and wooden crate) and storage periods $(0,3,6,9$ \& 12 days) which were arranged in Complete Randomized Design (CRD) with three replications. Highly significant effect of storage temperature, packages and storage period on weight loss, soft rot and firmness of mango fruit were observed during storage at probability level of $(\mathrm{p}<0.05)$ while $\mathrm{Ca}$ and $\mathrm{Mg}$ content of fruit were not affected significantly. Maximum weight loss (33.24\%) and soft rot percent (100\%) of mango fruit were observed at open air for $9^{\text {th }}$ day of storage, except firmness (6.10) was obtained at cool chamber during harvested day. Whereas the minimum weight loss (3.74\%), soft rot percent $(1.11 \%)$ and firmness $(0.52 \mathrm{~N})$ of mango fruit were observed at cool chamber for lowest day of storage. It can be concluded that, the results of physiological weight loss and soft rot incidence were increased significantly as increased storage period at the entire observation whereas firmness, calcium and magnesium content of fruit were decreased as increased storage periods. Mango fruits stored in pusa zero energy cool chamber was exhibited lower weight loss and soft rot incidence while firmness, $\mathrm{Ca}$ and $\mathrm{Mg}$ contents were exhibited higher as compared to open air storage condition. Based on the present study the combinations of cool chamber + plastic crate + storage up to $12^{\text {th }}$ days were recommended for mango fruit under Arba Minch condition.
\end{abstract}

Keywords: Mango Fruit, Mineral Content, Physical Characteristic, Package Material and Storage Condition

\section{Introduction}

Mango (Mangifera indica L.) is a king of fruits due to its attractive appearance, delicious taste, excellent flavor, high nutritional value, variety diversification, year-round production and wide adaptability on different growing conditions. The world production of mango was 31.7 million tons in 2009 and was estimated to be 34.4 million tons in 2010 [1]. Mango is commercially grown in 90 countries and known as the most important tropical fruit crop of Asia.It is also considered as fruit of excellence and thus has prominent position among commercial fruits grown in Ethiopia. The major production countries are
India, China, Thailand, Indonesia, Philippines, Pakistan, and Mexico [1]. Mango contains over 20 different vitamins and minerals, and presents a rich source of vitamins $\mathrm{C}$ and A, both of which are important antioxidants. Higher intake of these vitamins and minerals are needed to reduce the higher percentage of night blindness and anemia prevalent among children.

Mango being a highly perishable fruit possesses a very short shelf life and reach to respiration peak of ripening process on $3^{\text {rd }}$ or $4^{\text {th }}$ day after harvesting at ambient temperature [2]. The shelf life of mango varies among its 
varieties depending on storage conditions. It ranges from 4 to 8 days at room temperature and 2-3 weeks in cold storage at $13^{\circ} \mathrm{C}[3]$. This short period seriously limits the long distance commercial transport of this fruit [4]. Usually after harvesting, the ripening process in mature green mango takes 9-12 days [5].

Most of the horticultural crops including fruits and vegetables begin to deteriorate shortly after harvest. Refrigerated cool storage is considered to be the best method of storing fruits and vegetables. However, this method is not only highly energy intensive but also involves huge capital investment. The present trend world over is to develop a simple low cost cooling system for storage of fruits and vegetables. In order to overcome the problem of on farm storage, low cost environment friendly Pusa Zero Energy Cool Chambers have been developed Indian Council of Agricultural Research [6] The greatest importance of this low cost cooling technology lies in the fact that it does not require any electricity or power to operate and all the materials required to make the cool chamber are available locally, easily and cheaply. Even an unskilled person can install it at any site, as it does not require any specialized skill. Most of the raw materials used in cool chamber are also re-us sable. The cool chamber can reduce the temperature by $10-15^{\circ} \mathrm{C}$ of ambient temperature and maintain high relative humidity of above $90 \%$ throughout the year that can increase the shelf life and retain the quality of fresh horticultural produce.

There is no proper means of post-harvest handling of mangos at harvesting, retailer and wholesaler levels. Due to improper handling, inadequate storage, lack of packaging and lack of harvest technical knowledge producers and traders faced about 20 to $30 \%$ losses [7]. Even though the country is experiencing such a huge loss of fruit, very little emphasis has been given to post-harvest handling of perishable produce.

Mango is the largest produced tropical fruit in Gamo-Gofa Zone, Southern Ethiopia, production of mango at Arba Minch ZuriaWoreda is $126,800 \mathrm{qt}$ and total area coverage is 634 ha [8]. In spite of its largest production the availability is restricted to only a few months due to its poor shelf life as a result farmers has not been gained proper income from the crop. Despite the untapped potentials and opportunities of Gamo-Gofa lowland climates for tropical fruit production, the achievements so far are not satisfactory. There have been low levels of research done on lowland fruits except some variety adaptation trial by SNV and Vita NGO's to substitute local mango by apple mango.

The major objective of the study was to investigate the influence of storage temperature, packaging material and storage period on physical characteristics and mineral content of mango fruit and identify the optimal storage conditions for prolonged shelf life of mango fruit.

\section{Research Methodology}

\subsection{Experimental Site}

The experiment was conducted in 2014/15 at Kulfo campus Horticulture Laboratory, Arba Minch University. Moreover, Pusa Zero Energy Cool Chamber (PZECC) was constructed at same campus. Arba Minch tow is located at $6^{\circ}$ 2' $\mathrm{N}$ latitude and $37^{\circ} 33^{\prime} \mathrm{E}$ longitude, far about $500 \mathrm{~km}$ from Addis Ababa and at an altitude of about 1200 m.a.s.l. Its average temperature and annual rainfall is $29^{\circ} \mathrm{C}$ and $900 \mathrm{~mm}$, respectively.

\subsection{Construction of Pusa Zero Energy Cool Chamber (PZECC)}

The construction of zero-energy cool chamber was followed as per Indian Council of Agricultural Research [6]. A rectangle shape floor measuring $200 \times 150 \mathrm{~cm}$ was made with bricks. Over this, a double wall was erected to a height of $100 \mathrm{~cm}$ leaving a gap of $7.5 \mathrm{~cm}$ between the double walls. The walls were drenched with water. Wet fine river sand was filled in the $7.5 \mathrm{~cm}$ gap between walls. A bamboo frame $(200 \times 150 \mathrm{~cm})$ was made to cover the chamber. A thatched shed was constructed over the chamber in order to protect it from direct sun or rain. During the experimental period, the sand between the walls, bricks and top cover of the chamber were kept moist with varied quantities of water as per the treatments through drip system with plastic pipes and micro tubes connected to an overhead water source. The stored mango fruits were evaluated every three days intervals for total 12 days.

\subsection{Experimental Materials}

Green matured and unripe good quality mango fruits of the same size were purchased from "Lante Kebele" local farm near Arba Minch town and brought to the laboratory of Horticulture Department College of Agriculture, Arba Minch University. Packaging materials include plastic and wooden crates were used. The mango fruits were washed with cold tape water in order to remove field heat and dried with muslin cloth. The fruits were stored at open air (in average $32^{\circ} \mathrm{C}$ with $70 \% \mathrm{RH}$ ) and pusa zero cool chambers (in average $18^{\circ} \mathrm{C}$ with $\left.90 \% \mathrm{RH}\right)$ to determine their physical characteristics, decay/soft rot and some minerals.

\subsection{Experimental Design and Treatments}

The trial was laid out in a complete randomized design (CRD) with three replications in factorial experiment (Table 1). The treatments were comprised storage condition(ambient temperature and pusa zero energy cool chamber), packaging materials (plastic and wooden crate) and storage periods $(0$, $3,6,9 \& 12$ days). 
Table 1. Experimental layout.

\begin{tabular}{lllll}
\hline \multicolumn{4}{c}{ Factors (postharvest treatments) } \\
\hline $\begin{array}{l}{ }^{1} \text { Storage } \\
\text { periods } \\
\text { (days) }\end{array}$ & $\begin{array}{l}{ }^{2} \text { Pusa zero energy cool } \\
\text { chamber }\end{array}$ & $\begin{array}{l}{ }^{2} \mathrm{Room} \text { temperature } \\
\text { (RT)/Open Air }\end{array}$ \\
\cline { 2 - 5 } Woodencrate & $\begin{array}{l}{ }^{3} \text { Plastic } \\
\text { crate }\end{array}$ & $\begin{array}{l}{ }^{3} \text { Wooden } \\
\text { crate }\end{array}$ & $\begin{array}{l}{ }^{3} \text { Plastic } \\
\text { crate }\end{array}$ \\
\hline 0 & $\mathrm{Cc} * \mathrm{~Wb} @ 0$ & $\mathrm{Cc} * \mathrm{~Pb} @ 0$ & $\mathrm{RT} * \mathrm{~Wb} @ 0$ & $\mathrm{RT} * \mathrm{~Pb} @ 0$ \\
3 & $\mathrm{Cc} * \mathrm{~Wb} @ 3$ & $\mathrm{Cc} * \mathrm{~Pb} @ 3$ & $\mathrm{RT} * \mathrm{~Wb} @ 3$ & $\mathrm{RT} * \mathrm{~Pb} @ 3$ \\
6 & $\mathrm{Cc} * \mathrm{~Wb} @ 6$ & $\mathrm{Cc} * \mathrm{~Pb} @ 6$ & $\mathrm{RT} * \mathrm{~Wb} @ 6$ & $\mathrm{RT} * \mathrm{~Pb} @ 6$ \\
9 & $\mathrm{Cc} * \mathrm{~Wb} @ 9$ & $\mathrm{Cc} * \mathrm{~Pb} @ 9$ & $\mathrm{RT} * \mathrm{~Wb} @ 9$ & $\mathrm{RT} * \mathrm{~Pb} @ 9$ \\
12 & $\mathrm{Cc} * \mathrm{~Wb} @ 12$ & $\mathrm{Cc} * \mathrm{~Pb} @ 12$ & $\mathrm{RT} * \mathrm{~Wb} @ 12$ & $\mathrm{RT} * \mathrm{~Pb} @ 12$ \\
\hline
\end{tabular}

Where: PC; Plastic Crate and WC; Wooden crate, Cc; Pusa Zero Energy Cool Chamber, three Factors of Postharvest Treatments such as ${ }^{1}$ Storage Periods, ${ }^{2}$ Storage Conditions and ${ }^{3}$ Packaging Materials

\subsection{Data Collection}

Laboratory analysis of mango fruit for the entire physical parameters and mineral contents were conducted at Chemistry lab, Arba Minch University. The data of physiological weight loss, soft rot, calcium and magnesium contents of mango fruits were determined. During experiment two mango fruits were taken randomly from each treatment within an interval of 3 days for total 12days of storage period at open air and cool chamber. The experimental procedures of the entire parameters were described in detail as follows:-

\subsection{Physical Properties of Mango Fruit}

\subsubsection{Physiological Weight loss (\%)}

The weight of the fruit was measured during the storage period with an electronic balance (Fx-3000; A\&D Company, Japan) with an error range of $0.01 \mathrm{~g}$. The loss in weight was expressed as percentage of the original fresh weight of the fruit. The weight loss of mango fruit was calculated by differences between initial weight and final weight divided by initial weight and multiplied by $100[9]$. The weight loss of packaged mangoes in perforated plastic and wooden crate was observed after an interval of 3 days for a period of 12 days. The weight loss of the same sample was recorded periodically during the storage period.

$$
\% \text { Weight loss }=\frac{\text { Weight of first interval }- \text { Weight of second interval } \times 100}{\text { Weight of first interval }}
$$

\subsubsection{Fruit Firmness}

Fruit firmness was determined with a digital hand held penetrometer (Model KM-1, Fujiwara, Japan) by taking five readings per fruit on opposite sides along the fruit equatorial region. The skin of fruit was removed at the reading spot to ensure that pulp firmness, rather than skin firmness, was assessed. Firmness was expressed in Newton (N).

\subsubsection{Soft rot (\%)}

Percent soft rot in each replication of treatments was examined visually and counted during 12 days storage and their disease percentage of fruits was calculated by formula as under:

$$
\text { Percent disease incidence }(\%)=\frac{\text { Number of diseased fruits }}{\text { Total number of fruit }} \times 100
$$

\subsection{Determination of Minerals}

Ash content was determined by the process of AOAC method [10] and then minerals content was determined according to standard method. Calcium (Ronald and Ronald, 1991) and magnesium (CHEM, 2008) contents were determined by titration process[11-12].

\subsection{Statistical Analysis}

Significance tests were made by analysis of variance (ANOVA) for complete randomized design with factorial arrangement according to Gomez and Gomez [13]. ANOVA was carried out with a SAS (version 9.1) statistical procedure. Comparisons of the treatment means were done using Duncan's multiple range tests at $p \leq 0.05$.

\section{Results and Discussions}

The data was analyzed on physical characteristics includes physiological weight loss, firmness and soft rot/decay and also some mineral parameters were comprised calcium $(\mathrm{Ca})$ and magnesium (Mg) contents of mango fruit.The statistically interpreted results of the entire parameters are given below in the Figures.

\subsection{Physiological Weight Loss}

Physiological weight loss of mango fruits were increased significantly $(\mathrm{P}<0.05)$ due to the combination effect of storage condition, packaging material and storage duration. The maximum weight loss $(33.24 \%)$ was recorded in mango fruit stored in plastic crate at open air for $9^{\text {th }}$ days whereas the minimum weight loss $(3.74 \%)$ was recorded in fruits stored in plastic crate at cool chamber for $6^{\text {th }}$ days (Figure 1). Mango fruits which were stored in both packages at open air were exhibited the highest weight loss than that of stored at cool chamber, this perhaps due to the variation of temperature. The loss of weight significantly increased following an ascending order of ranking throughout the storage period and significantly highest loss in weight of mango fruit was observed at last day of storage, due to transpiration and respiration of fresh fruits. The reduction of weight loss could be due to the presence of physical barrier in gas diffusion through fruit stomata by which gas exchange takes place between internal tissues and external atmospheres. The weight loss in fruits depends on the structure of the skin and nature of waxes on the surface of the fruit [14]. 


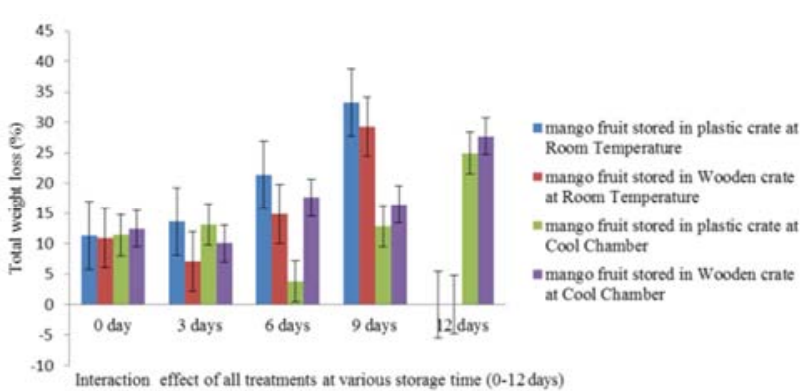

Figure 1. Effect of storage condition, packaging materials and storage duration on total weight loss (\%) of mango fruit.

\subsection{Firmness}

Firmness of mango fruit was decreased significantly $(\mathrm{P}<0.05)$ due to the combination effect of storage condition, packaging material and storage duration. The highest $(6.10 \mathrm{~N})$ firmness was recorded in fruits stored in plastic crate at cool chamber during harvested days followed by fruits stored in wooden crate at cool chamber and open air with 0.52 and $0.59 \mathrm{~N}$, respectively (Figure 2\&3). The fruit firmness was decreased with every increment of storage periods, might be due to the breakdown of insoluble pectic substances to soluble forms by a series of physic-chemical changes that caused by the action of pectic enzymes formed in the tissues during ripening [15]. The declining concentration of calcium might reduce calcium pectin interactions, allowing free release into flesh leading to reduce firmness as the fruit ripen and further breakdown caused shriveling or over ripening of mango fruit. The faster reduction in firmness score in fruits which were stored at open air when compare to fruit that stored at cool chamber; this might be due to accelerated ripening process in free atmospheric conditions of storage temperature. These findings are correlated with Opara et al. (2000) in Vietnam, who reported that firmness of mango was highly dependent on storage temperature and increase in temperature $\left(27^{\circ} \mathrm{C}\right)$ accelerated ripening, reduced firmness from 63.4 to $26 \mathrm{~N}$ with the passage of storage time and fruit quality became unacceptable between $10-15$ days as compared to cold storage of fruit at $7^{\circ} \mathrm{C}$ or $12^{\circ} \mathrm{C}$ maintained fruit firmness ( 63.7 to $37.6 \mathrm{~N}$ ) during 25 days of storage and extends the storage life to over 3 weeks [16].

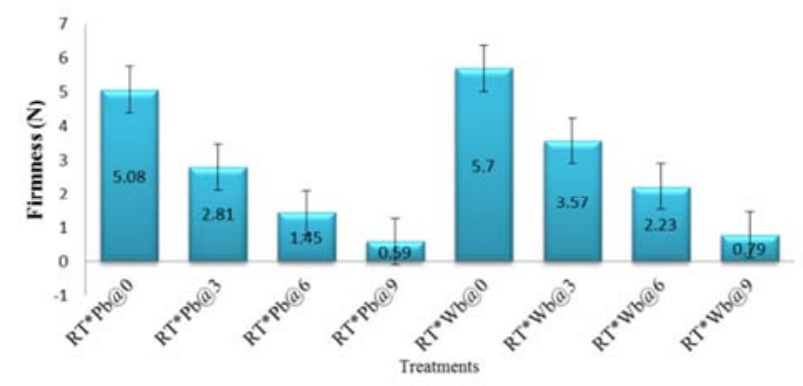

Figure 2. Interaction effect of ambient temperature, packaging material land storage period on firmness of mango fruit. RT: Room/ambient Temperature, *: interaction effects, $\mathrm{Pb}$ : plastic crate box, Wb: wooden box, and @: at storage periods (0-12 days).

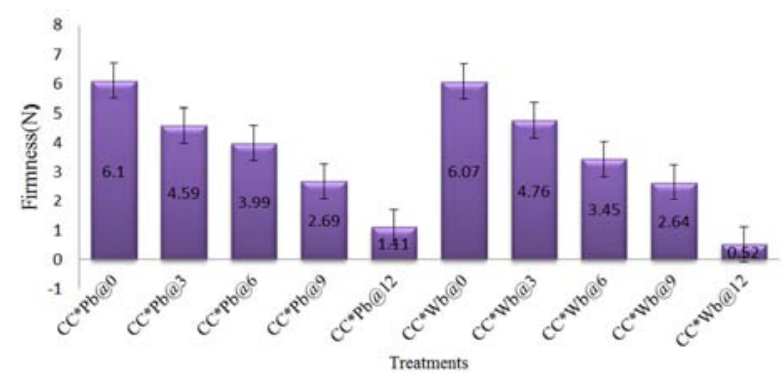

Figure 3. Effect of cool chamber, packaging material and storage period on firmness of mango fruit. CC: Cool Chamber, *: interaction effects, $P b$ : plastic box,Wb: wooden box, @: at storage periods (0-12 days).

\subsection{Soft Rot \%}

Soft rot percent of mango fruit was increased significantly $(p<0.05)$ for entire treatments due to the combination of storage condition, packaging material and storage period. The maximum soft rot incidence $(100 \%)$ was observed after $9^{\text {th }}$ days of storage in both packages at open air followed by fruit stored in plastic crate at cool chamber for $12^{\text {th }}$ days with $88.89 \%$ (Figure 4). The minimum soft rot incidence (1.11\%) was observed in fruit stored in wooden crate at cool chamber for $3^{\text {rd }}$ days. The soft rot of mango fruit increased with every increment of storage periods to the maximum of $100 \%$ after $12^{\text {th }}$ days of storage at open air while there was no soft rot incidence at harvested day of storage. It is found that fruits are highly susceptible to decay because of soft texture and high moisture content [17]. The increase in soft rot incidence with increasing storage duration varied significantly with storage conditions and packaging materials.

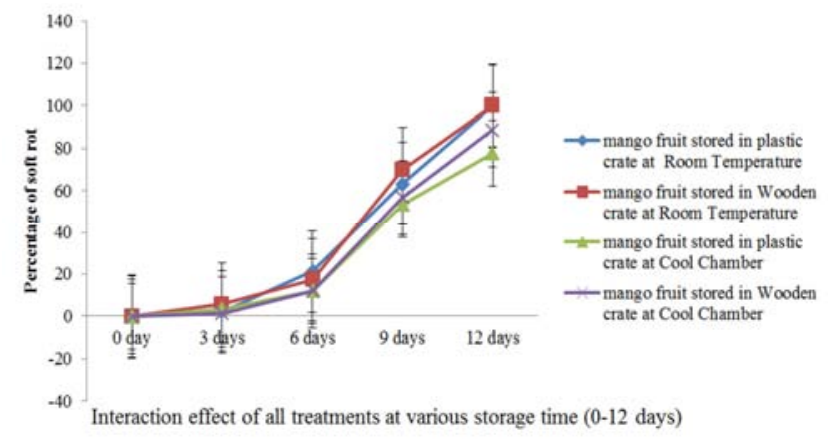

Figure 4. Effect of storage condition, packaging materials and storage period on soft rot incidence (\%) of mango fruit.

\subsection{Calcium and Magnesium}

Calcium and magnesium content of fruits were exhibited slightly considerable different $(p<0.05)$ for the entire treatments which were stored at cool chamber and open air, respectively. On the other hand, $\mathrm{Ca}$ and $\mathrm{Mg}$ content of fruits were not exhibited significant different $(p>0.05)$ between the entire treatments stored at open air and cool chamber, respectively. The maximum calcium $(11.26 \mathrm{mg} / 100 \mathrm{~g}$ in $\mathrm{dwt})$ and magnesium $(17.42 \mathrm{mg} / 100 \mathrm{~g}$ in $\mathrm{dwt})$ were observed in fruits stored in wooden crates at cool chamber and open air for $0^{\text {th }}$ and $6^{\text {th }}$ days, respectively (Figure $5 \& 6$ ). While the 
minimum $\mathrm{Ca}(1.70 \mathrm{mg} / 100 \mathrm{~g}-\mathrm{dwt})$ and $\mathrm{Mg}(14.72 \mathrm{mg} / 100 \mathrm{~g}-$ dwt) contents were obtained in fruit stored in wooden and plastic crates at cool chamber and open air for $12^{\text {th }}$ and $3^{\text {rd }}$ days, respectively. The calcium range was similarly (16.0 $28.0 \mathrm{mg} / 100 \mathrm{~g}$-fwt) to that reported by West et al. (1988) for some fruits in East Africa and within the range (7.4 - 55.1 $\mathrm{mg} / 100 \mathrm{~g}$-fwt) reported by Aremu and Udoessien (1990) for some Nigerian fruits [18]. Moreover, the present result was laid under the range of $\mathrm{Mg}(7.7-118.0 \mathrm{mg} / 100 \mathrm{~g}$-fwt) that was reported by Aremu and Udoessien (1990) for Nigerian oranges but was higher than the range $(6-14 \mathrm{mg} / 100 \mathrm{~g}$-fw) reported by Hunt et al. (1991) [19].

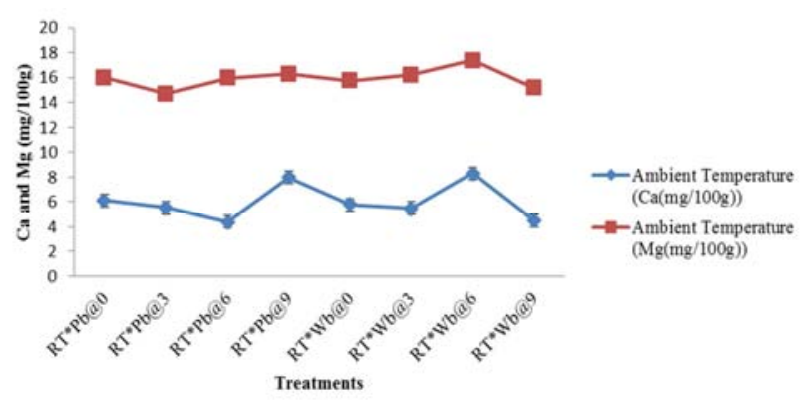

Figure 5. Effect of ambient temperature, packaging material and storage period on calcium and magnesium of mango fruits. RT: Room/ambient Temperature.*: interaction effects, $\mathrm{Pb}$ : plastic crate box, $\mathrm{Wb}$ : wooden box, and @: at storage periods (0-12 days).

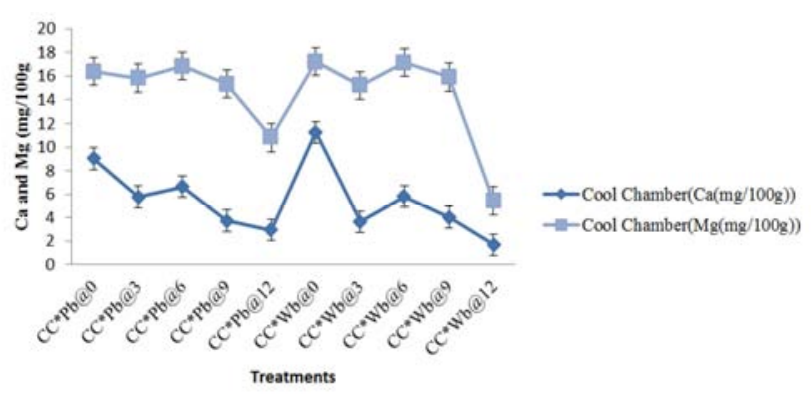

Figure 6. Effect of cool chamber, packaging material and storage period on calcium and magnesium of mango fruit. CC: Cool Chamber, *: interaction effects, Pb: plastic box, Wb: wooden box, @: at storage periods (0-12 days).

\section{Conclusion and Recommendation}

In conclusion, there was high significant difference in mango fruit of physiological weight loss, firmness and soft rot incidence due to the interaction effect of storage condition, packaging materials and storage period whereas slight significant effect on calcium and magnesium. Mango fruit stored in plastic crate at cool chamber up to $12^{\text {th }}$ day of storage was obtained best quality in physical and mineral parameters when compared to fruits that of stored under open air. The results of physiological weight loss and soft rot incidence were increased significantly as increased storage period at the entire observation except for firmness; and calcium and magnesium content of fruit were decreased as increased storage periods. Mango fruits stored in pusa zero energy cool chamber was exhibited lower weight loss and soft rot incidence; and higher firmness, $\mathrm{Ca}$ and $\mathrm{Mg}$ contents as compared to open air storage condition. Based on the present study the combination of cool chamber + plastic crate + storage up to $12^{\text {th }}$ days were recommended for mango fruit in particular and for all fresh horticultural crops in general under Arba Minch condition.

\section{References}

[1] FAO, 2011. Tropical fruits compendium. http://www.fao.org/docrep/meeting/022/am481t.pdf.

[2] Narayana, C. K., R. K. Pal and S. K. Roy. 1996. Effect of prestorage treatments and temperature regimes on shelf-life and respiratory behaviour of ripe Baneshan mango. J. Food Sci. Tech., 33: 79-82.

[3] Carrillo, L. A., F. Ramirez-Bustamante, J. B. Valdez-Torres, R. Rojas-Villegas and E.M. Yahia. 2000. Ripening and quality changes in mango fruit as affected by coating with an edible film. J. Food Qlty., 23: 479-486.

[4] Gomer-Lim, M. A. 1997. Post harvest physiology. In: The Mango: Botany, Production and Uses. (Es.): R. E. Litz. pp. 425-446, CAB International, New York.

[5] Herianus, J. D., L. Z. Singh and S. C. Tan. 2003. Aroma volatiles production during fruit ripening of Kensington Pride mango. Postharvest Biol. Technol., 27: 323-336.

[6] ICAR Newsletter, 3, 1-4 (1997).

[7] Tahir FM, Pervaz MA, Hameed C (2002). Losses of mango fruit after harvest and its control. Agric. Digest. 37: 62-64.

[8] Woreda Burea of Agriculture and Rural Development. 2009. "Survey Report on Production of mango". Unpublished: Arbaminch, Ethiopia.

[9] Moneruzzaman KM, Hossain ABMS, Sani W, Saifuddin M, Alenazi M (2009) Effect of harvesting and storage conditions on the post harvest quality of tomato (Lycopersicon esculentum Mill) cv. Roma VF. Australian Journal of Crop Science. 3: 113-121.

[10] AOAC. 2005. Official Methods of Analysis. $18^{\text {th }}$ edn., Association of Official Analytical Chemists, Gaithersburg, Maryland, USA.

[11] Ronald, S. K. and Ronald, S. 1991. Pearson's Composition and Analysis of Foods, $9^{\text {th }}$ edn., p. 8-42. England: Addision Wesley Longman Ltd.

[12] Chaturvedi, U. C., Shrivastava, R. and Upreti, R. K. 2004. Viral infections and trace elements: A complex interaction. A review article. Current Science 87(11): 1536-1554.

[13] Gomez, K. A. and Gomez, A. A. (1984).Statistical Procedure for Agricultural Research.2nd ed. John Wiley and Sons, New York.pp. 680.

[14] Veravrbeke, E. A., P. Verboven, P. Oostveldt and B. M. Nicolai (2003). Predication of moisture loss across the cuticle of apple (Malussylvestrissupsp. Mitis(Wallr.) during storage: part 2. Model simulations and practical applications. Postharvest Biol. Technol. 30: 89-97.

[15] Weichmann, J., 1987. Post Harvest Physiology of Vegetables. Marcel Bekker, Inc, New York, P: 145. 
[16] Opara, L. U., H. X. Nguyen and Levanto, 2000. Postharvest technology for Vietnamese Buoi mango. Quality assurance in agricultural produce. ACIAR proceedings, 100: 633-638.

[17] Spotts, R. et al, 1999.Variability in postharvest decay among apple cultivars. Plant Dis. 83: 1051-1054.
[18] Aremu CY and Udoessien EI, 1990. Chemical estimation of some inorganic elements in selected tropical fruits and vegetables.Food Chem. 37: 229-234.

[19] Hunt CD, Shuller TR, Mullen ML, 1991.Concentration of boron and other elements in human foods and personal-care products. J. Am. Diet. Assoc. 91: 558-568. 